\title{
Academic insight on application and challenges of software to develop educational medical english writing
}

\author{
Jafar Asgari Arani \\ English Department, Kashan University of Medical Sciences, Iran
}

\begin{tabular}{l} 
Article Info \\
\hline Article history: \\
Received Nov 12, 2019 \\
Revised Jan 20, 2020 \\
Accepted Feb 2, 2020 \\
\hline
\end{tabular}

\section{Keywords:}

Academic

Education

Skype

Medical Writing

University

\begin{abstract}
This research has thrown up many questions in need of further investigation.There was an expressive quantitative-qualitative research, which a common investigation form was used in. The dialogue item was also applied to discover if the contributors asserted the media-based attitude supplements their learning of academic English writing classes or not.Data recounted academic" insights toward using Skype as a sustaining implement for lessons releasing based on chosen variables: their occupation, year of education, and knowledge with Skype discovered that there were no important statistical differences in the use of Skype units because of medical academics major knowledge. There are statistically important differences in using Skype units. The findings also, disclosed that there are statistically significant differences in using Skype units due to the practice with Skype variable, in favors of academics with no Skype use practice. Skype instrument as an instructive media is a positive medium to be employed to supply academic medical writing data and assist education. Academics who do not have enough time to contribute in classes believe comfortable using the Skype-based attitude in scientific writing. They who took part in the course claimed that their approval of this media is due to learning academic innovative medical writing.
\end{abstract}

This is an open access article under the CC BY-SA license.

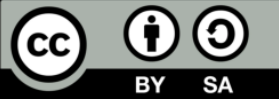

\footnotetext{
Corresponding Author:

Jafar Asgari Arani,

English Department, Faculty of Medicine,

Kashan University of Medical Sciences,

Islamic Republic of Iran.

Email: J.Asgari@yahoo.com
}

\section{INTRODUCTION}

To make it easy to communicate, and collaborate with various people applying a variety of teaching methods such as writing, link allocating, and voice or video evidences., some social networks as Skype, Twitter, and Linked-in only to make it possible to probably transmit, collect and assign information. Information and communication technology (ICT) has been a critical component of teaching and learning in higher education over the last few decades. One particularly important trend we have recently witnessed with regard to the use of ICT is the increasing reliance on Skype tools not only in everyday jobs, but also within specialized and educational environments [1]. To approach academics' educational necessities, interests and claims, many universities and colleges have developed a variety of podiums in these networks. Therefore, recently, researchers have scrutinized the competence of these meetings in different teaching and learning grounds [2,3]. Many Android applications are at present being developed such as WhatsApp, Skype and GO SMS Pro, the most stupendous messenger applications among the university's academics [4].

To take place to emphasize the ability of academics in scientific writing, the survey requires some other new educational instruments in teaching [5].This is mostly as from the instructive stand point; academics are used to the treating, traditional, and additional approaches of teaching and learning [6,7]. The difficulty 
keeps on as Nowlan [8] concludes that interaction Boyer hour for academics and lecture is another obstacle to be run intoed. According to him one or two hour of teaching and learning English per week is not sufficient to allow the academics to implement and extend English and obtain academic writing skill. Therefore, there is a need to find the resolution to the above dilemma specially in preparing setting to the academics to use English language and learn the way to accomplish a valuable result even outer the classroom.

Using new technology can significantly improve blended learning [9], but can have a major role in also supporting on-campus teaching. Skype have been employed in educational activities to admit course substances, obtain information connected to students' presentation, and to support argument and disclosing between students and teachers [10]. It is therefore evident that these tools such as Skype can have a significant involvement to new health care teaching, because these devices might present opportunities to develop teaching and learning.

\section{PROMOTING PREMISES TO SOCIAL MEDIA LANGUAGE KNOWLEDGE}

Designed for teachers attracted in incorporating features of social media with their educators, it is momentous to remember the premise and present pedagogic positions monitoring language learning with media. Along with Blyth [11], there are three special categories to language learning analyses [12].

a. Technical: Technical suppositions are those that explicates as an improvement stage, covering of explorative and expressive researches. Researches aim at assessing the potential advantages of the individual tools, attending to the means these instruments may change the perception of traditional learning in the classroom. Appropriate to Blyth's claims, studies in this part are suitable for teachers tracking to use a special social networking instrument and illustrate further research in the area of social system.

b. Psycholinguistics: Psycholinguistic approaches to language achievement aim the significance of social contacts and detaining. A collection of recent surveys $[13,14]$ have pointed to that Interaction Hypothesis in language development is realized by person-to-person communication and the linguistic communications that occur. In reality, prominent appraisal in CALL has long suggested the assessment of achievement issues within a consistent, psycholinguistic agenda $[15,16]$.

c. Sociocultural: Language and social communication engage in recreation of a function in human growth, and purpose as cultural concerns that may lead to the appearance of knowledge supplied by members of the society [17]. Allowing for this mode this might supply social networking, online associations with other learners and experts around the world can believably propose a rich site for socio-cultural language management $[18,19]$.

These entire three hypotheses to language learning are confirmed to request the method the media matches to the various forms.

\section{BELIEFBASIS}

The major justification behind this study is Self-Determination Theory (SDT). It is considered a general theory of human motivation and personality concentrating on the dialectical associations between growth-oriented human beings and social environments assisting or obstructing people's stimulation to recognize their prospection [20-23]. In their 1994 survey, Deci \&Ryan and Krashen [24] set down three factors augmenting self-determination in the classroom. Autonomy can be described as the level of principals that academics have when they complete academic tasks and the quantity of option they have concerning when and how to execute them [25]. This also occurs through the decisions they can make during the learning progression [26]; these selections assist them become more self-sufficient and autonomous in making decisions about their learning.

The Skype scenery, which is free from time and region limitations and makes access possible to different people and reserves, helps academics solve their problems in their own time, to learn via an opportunity presenting methodology and to learn separately. It can be anticipated that academics learning a foreign language on educational Apps sense more self-sufficient than rest in a face-to-face collection. Honesty refers to emerging and activating skills for the management and direction of the situations.

SDT defines honesty as the need to be effective in communications with the social environment while practicing every moment to affirm and employ ones capacities and abilities [23]. Academic' feelings of honesty increase when they are certain that their learning activities and tasks adjust their knowledge and skills. Moreover, the activities academics are anticipated to perform should be both interesting and stimulating in order to devotedly raise contributors' motivation. Tasks should also provide contributors an opportunity to respond and to believe immediate comment [26, 7]. Lastly, trust refers to a need for belonging to or trusting on a group. Classrooms convene this standard through providing various opportunities of connection and interconnection for academics. Reaction is in fact, one response to the need of confidence in participants and 
makes it possible for them to complain atopic and to help and constructively appraise each other, thereby increasing their self-respect [28]. It is obvious that one of the most important positions of online social networks is systematizing communication and social interaction [29]. Communication in these networks, other than being free from time and space limitations, is possible with diverse types of forms such as audio, visual, written, and short messages that are easy to use. Therefore, one may expect that the use of these networks will enhance concerns of dependence in the scheme contributors. Academics learning a foreign language on educational Apps feel more depended on other academics than do teachers in a face-to-face class.

\section{CURRENT DIDACTIC CHANCES OF SKYPE}

Dissemination and correspondence firstly realized in the online situation can be brought into the classroom. English language educators can apply the creative didactic subjects positioned in the social networking sites to get education of the English language. There are groups committed to learning English languages in EFL and ESL circumstances on social networking sites. These groups provide their members with regular modifications of grammar, vocabulary, and much new information. English language learners can also entry links distributed on the group page by other members. Skype supplies diverse kinds of educational chances for classrooms. Academics can connect with other academics, increase their information, and cooperate with colleagues. They can employ Skype to allocate projects, improve their language skills, and correspondence paper type about particular books and journal articles with other academics having tried the same textbooks and articles or having offered their own plans to their group.

Skype, a software application for online communication, has been applied in classes at various levels, offering much potential for teaching and learning [30-33]. Skype is an open instrument permitting users to make printed, audio and video over the Internet applying power point, word, mp4, and so on. Although Skype is a scientific instrument, its free version is being applied increasingly among teachers and schools involved in people education schemes [34, 9]. For example, Skype is being applied to assist scholarly investigative thoughts substitution. Academics in different parts of the world are joined, each is a native speaker of the language with exclusive research ideas that the other wishes to be notified. In discussion and communication over instructional channel, they take turn between the two scientific society's languages [35].

Educators also supply Skype in single methods to meet educational goals. The videoconferencing division of the software is priceless in that it supplies a way to join university instructors speaking different languages, maintain virtual field trips, and extend to professionals in dissimilar areas of study. These practices allow academics and opportunity to use what they are learning in the classroom to real-life practices and attain further learning opportunities [36].

Skype in the classroom is a new free educational media that has set up on its website. It provides teachers with a way to make their classrooms more expansive and appealing. Skype in the classroom is an examination that teachers can sign up for that will permit students to meet up others, entertain and send homework, and distribute ideas. Teachers can cooperate with each other around the world and plan different new learning and training exercises for their class educational resources. There should be a variety of tracks in Skype, in which L2 educators can contribute. Teachers can apply Skype's search tool to reach experts in their scientific areas of their resolutions [37].

\section{ENGLISH INSCRIPTION}

The Skill of writing being shown to be one of the most complex language abilities learners are believed to obtain [27]. In spite of spending many years raising their writing skills, most second language learners (L2) of English are described with barriers in their attempts. These obstructions among others are attributable to the difficulties of the writing skill [38]. Writing, as a complex and extended process, is further finished harder for the L2 learner due to sociological, sociocultural, linguistic, and cognitive factors [39].

To improve writing difficulties tackled by L2 learners, some current surveys pursue [40] temporary structure strategies in a blended instruction (face-to-face and online) class applying Skype to discover if students' writing execution could be strengthened. Temporary structure refers to the procedure of supporting a person to make a homework that is unfamiliar or further than his/her is capability. Through the temporary structure process, learners are helped to do parts of exercises within their ability, and the adult scaffolds the rest.

Macharaschwili and Coggin [41] illustrated the implementation of Skype in a blended classroom situation. They advocated that the face-to-face communications provided through Skype proposed immediate conclusion that would not be possible in an online gatherings. They indicated that face-to-face communications using Skype for distance students led to student achievement and completion. 
The surveyor accomplished a survey to discover the impact of Skype for language learning in Tandem [42]. Elia expanded to the argument that Skype language learning over "Mixxer" can be an influential application to be widely supported and experimented. According to her study, Skype might be a valuable mean and a trustworthy aid to EFL learners who always challenged problems in having written connection with native speakers.

Beltrán [43].in a research analyses the function of Skype chat for rising writing skills. Beltrán pointed out that it elevated students' stimulation by means of technology and was a chance to augment the teacher's program.

Another investigator emphasized in a plan on the teaching and learning of English by means of Skype conference calls Romaña Correa [44]. The research outcomes suggest that Skype might be asserted as an inspiring computer-mediated communication channel to develop EFL learners' writing ability.

\section{DISCUSSION APPRAISAL}

As Gabriel [45] maintained conventional literacy alone is not adequate, unless it is developed by the capability to attain knowledge and to converse with a wider collection of publish and electronic media. The objective of this case study was to discover the awareness of teachers and academics about the efficiency of Skype as a temporary structure device to raise academic accomplishment for learners in online remedial English composition courses through communicating with their instructor.

As a result, the specific aim was to find out if Skype could be a successful tool for instructors to propose temporary structure to underprepared academics for the gaining of English composition skills. However, few studies have investigated the opinions of teachers and academics about the effect of Skype and similar mutual Web 2.0 technologies on student accomplishment in online asynchronous learning organizations. As Strang [46] asserted in a study on Skype in an online mathematics course explored that academics who took part in Skype-led based received a statistically higher final score than those in the control group. This investigation concentrated on the development of prepared academics, who due to their level and advanced course had already verified academic success. The literature review shows that Strang did not demonstrated whether Skype could be used to support and recover the learning and ability of first year online college academics and students. In a college course to determine the capacity of Skype along with other Web 2.0 technologies, a recent pilot study by Chou [47] concluded that this media could be used to support online collaborative learning. Chou found out that Skype, Podcasting, Skype, Blogging, and Wikis enhanced student learning in online discussions. He implied that further research should be done to pertain the instructional strategies into different learning environments. Parker, Boase-Jelinek, and Herrington [48] managed a qualitative research to scrutinize how synchronous group communicate within Skype was used in arrange level course for persevere teachers; how academics answered to it, and to what extent it resulted in an improvement of groups learning. This research did not concentrated on constructing instructor-student interactions, nor does it adjoin to the knowledge of whether or not Skype is adequate by low-learning academics to help recover their learning. Macharaschwili and Coggin [41] utilized Skype in a group of doctoral academics who met face-toface in a classroom. Skype was incorporated to connect academics that were not present to the classroom arguments. They investigated that Skype could be successfully used to connect distant learners to face-to-face classrooms. Cohen and Burkhardt [49] proposed and applied a synchronous librarian orientation service via Skype to teach educational information to university academics. They supervised group assemblies and a one one-on-one session with a student who needed supplementary guidance. They reported that Skype to be well situated for conveying information literacy instruction to groups of distant academics. They did not scrutinize whether academics observed any growth as an effect of Skype meetings.

There is a wide choice of Malaysian teenagers spend a lot of time outside of class using social networks like Skype, available in the literature Ab Manan et al [50]. It was because English is the language normally employed in these Media. Examiners explained that there are potential advantages when using a Skype collection in teaching ESL situations. The reason that rationalizes this situation is that "examiners suppose that the features recommended by Skype, with careful management, can be used as a powerful pedagogical instrument" (ibid, p. 1). The writers maintained that "blending conservative face-to-face teaching with online learning movements does not only resolve teachers' problem of insufficient class time but will make learning more attractive to the techno savvy younger learners" (ibid, p. 1). As well, investigators like Chenzi et al [51] have not treated Skype and other social networks into an ESL writing lessons in much detail. There has been little quantitative analysis for them to find the different advantages when Skype and other networks are used in the ESL lessons. Smethurst, [52] referred to the fact that an Australian educator has applied Skype for inter-school discussions with the absence of the face-to-face relations. Skype supplied many free services, together with voice and video data among persons from different geographical positions. Davis [53] hypothesized that learners have been utilizing Skype in their classroom for several years with a high 
level of achievement and handiness. More and more English language teachers have selected for integrating such promising technologies into their everyday teaching practices as such technologies can allow them as teachers and grow their teaching as well.

Skype was chosen for an investigation since as Mongillo and Wilder [54] affirmed; writing is a social proposal that necessitates the use of social forms. The prospective inferences for this research are that online lecturers may assist to augment the writing of online, underprepared academics with poor writing abilities by temporary structure knowledge via Skype to generate informal momentous learning relationships that will permit academics to become autonomous and self-assured.

Macharaschwili and Coggin [41] applied Skype in a group of doctoral academics convening face-toface in a classroom. Skype was incorporated to connect academics not present to the classroom arguments. They discovered that Skype could be successfully used to connect remote learners to face-to-face classrooms.

Analyzing lecturer and student awareness of the efficiency of Skype to temporary platform writing improvement extended three studies [55-57], which established that synchronous tools develop skill stages and that instructors or academics find value and significance in using the instruments.

Ciekanski and Chanier's [58] investigation was one of a few that mostly concentrated on teaching the writing procedure in an online synchronous setting, indirectly relating to three other elements of the present project: Skype, temporary structure, and corrective freshmen writing. Tutors and academics gathered over a 10- week period for eight meetings that lasted about an hour and a half each. The aim of the course was to expand professional English and capabilities in a group of academics who were less skillful in writing and speaking English (referred to as false learners by Ciekanski and Chanier and had not performed English between 15 to 30 years in a multimodal situation. This group was archetypal of the nontraditional academics registering in online universities. The podium used in this research was Lyceum, allowing learners to "link and communicate verbally in real time, contribute in text/chat, and study/adjust simultaneously textual or graphic assembled work".

Ciekanski and Chanier [58] came up with the fact that even when academics are engaged in the writing procedure, they do majority of the steps through Skype, discussing what and how to learn, rather than using the other styles for interfacing. They also perceived that learners counted on the devices of Microsoft Word processing software along with other software applications, indicating they made changes to their writing while using other instruments. Learners decided to contribute in multimodal discussion using synchronous means. Academics used multimodal policies (i.e., verbal and nonverbal communication) more than monomials policies. A multimodal knowledge situation assisted academics concentrated on the writing process more than the consequences due to its process-oriented nature. The examiners identified that using video would have been an interruption in this meticulous revision because speech is related to various types of writing. They also required more investigation to be accomplished in the region of writing in an online multimodal setting. Thus, the existing research on Skype assists to fill the gap because of its multi types comprising video, audio, text/chat, and screen sharing.

According to Mongillo and Wilder [54], using online technologies intensified the need to understand and write expository and explanatory writing, which were recognized as essential skills. It was helpful to the current study because the research employed Skype as a medium, along with other resources to help academics improve writing skills. Cohen and Burkhardt [49] research was proposed for librarians to help academics gain information in all four skills. Curriculum planers distinguish and attend to communication and writing shortages of nonnative-English-speaker academics [59] because American universities are comprised of academics from different countries. Cheng [59] observed the effect of computer mediated communication (CMC) and Vygotsky's temporary structure theory on a group of graduate academics talking English as a second language in a linguistic class. Cheng explicitly explained temporary structure for his study to denote the "support for learning and dilemma solving concerning academic writing using CMC." Because they supply chance for academics to request and present explanations, the evidence presented in this section suggests that Cheng assumed online argumentation forums in Skype gibbeted academics' understanding. He declared that an asynchronous setting is more contributing to assisting non-native speakers expand academic writing skills because it has waited construction, which provides academics time to internalize and manage information. Mongillo and Wilder [54] hypothesized that the online technological communication media, like Skype, present disenfranchised and disconnected academics with the motivation communication and stimulation that they require particularly because these academics are already skillful users of multiple technologies. Similarly, Murphy has approved a wider viewpoint and Rodriguez- Manzanares [60] who claims that promoted the necessity for technological mediums in distance education classes. Based on their survey, the means was exhibited as online teachers supplied immediate, productive to academics, illustrated distress of academics' improvement, personalized learning, and was available for instant receptiveness to academics' necessities. 


\section{SURVEY IMPLICATION}

The conservative academic writing technique of teaching is not adequate in progressing the academics' scientific writing ability. This study is conducted to explore if educating the academics in the use of circuitous LLS by Skype has any consequences on the learners' LLS use and their academic writing presentation.

The design of establishing blended knowledge to the English writing was commenced when the college grounds encountered the difficulty of physical classroom among the academics of the university.

The subsequent phases had motivated the researcher to assume this project:

- $\quad$ Recommending the idea on applying the social network location, Skype for academics as a method of instruction formally and informally

- Demonstrating the unlike levels of course incorporation at an instructors discarding.

- Supplying an option to the conventional lecture plan, forming an online classroom civilization, and amplifying teacher-content, teacher-learner and learner -learner communication

- Developing educational assortment, support dynamic learning through a learning society

- Examining the efficacy of on-line studying societies through Skype social media

- Deciding a choice teaching instrument Skype teaching societies to stable the conventional classroom knowledge is worth the cost of retooling and reforming

- Employing Skype, educators are capable to arrive at academics through new communication media and supply academics with experience and familiarity to precious instruments.

\section{INVESTIGATION QUERIES AND OBJECTIVES}

\subsection{Study inquiry}

1. What are the members' stage English introductory class academics ${ }^{\text {Iee }}$ feelings by means of "Skype in writing classes?

2. Is Skype helpful for progressing academics' stage introductory class academicse language writing abilities"?

The research scrutinizes using Skype as an additional learning means outside classroom. Three research questions were presented in the following:

1. What are the contributors' approaches toward Skype?

2. What are the contributor approaches toward learning outside classroom?

3. What are the contributors' approaches toward the Skype as a language-learning instrument in Basic English classes?

4. Can Skype assist develop academics' accomplishment in English base classroom?

The examiner assumes that Skype will benefit the learners in the inspiring stage of the writing process the most. However, the examiners are also open to explore how Skype might affect other features of writing and stimulus as a whole. To ease the exploration concerning the efficiency of Skype in teaching and recovering writing, the investigators prepared the following research questions:

1. How does Skype assist academics in their writing procedure?

2. What are some of the disputes teachers might face in assimilating Skype into the teaching of writing?

3. How does Skype manipulate the emotional field of the academics in writing skill?

\subsection{Justification of analysis}

The rationale of this case study was to discover the opinions of members about the efficiency of Skype. It should be possible to apply provisional structure instrument to raise academic accomplishment in English writing courses through cooperation with their lecturer. The result of communications between instructors and academics using Skype on the gaining of writing skills of underprepared academics appears as the occurrence of interest.

The survey is presumed to adjoin to linguistic knowledge about blended education to supply educational designers with improved acceptance about what works and what does not concerning the plan and the improvement of a blended classes. Finally, the results too will be helpful in facilitating decision makers establish the needs for the improvement and expansion of the blended education methodology in university situations. Having experimented years of teaching, the researcher is supposed to arrange some designs to meet the educational needs of the academics. 


\subsection{Contributers and assessment}

The sample participated were academics of Kashan University of Medical sciences; all having difficulties writing English well using selective sampling. This has to do with the reality that they are inclined to be alive with each other in their own language civilization, and keep on using the Persian language.

\section{PROCEDURE}

\subsection{Research Model}

The research was a descriptive qualitative research and a general inspection form was applied, as the goal of the research was to demonstrate the stance levels of the academics integrated in the study group towards Skype application, a Web 2.0 tool, along with a range of sub-dimensions. It comprised an investigational plan and the researcher scrutinized the academics in the setting to determine their feelings towards Skype application.

\subsection{Proposal}

The project is a quantitative domain of research with a non-randomized control group plan using a Skype group as experimental collection. The data analysis process selected in this research was a qualitative facts analysis. As it was said by Dey [61], "a qualitative facts analysis engages investigating data in its bits, and then 'beating' the bits together. It is a procedure of deciding data into ingredient parts to expose [their] features, elements, and structure. Similarly, Corbin and Strauss [62] describe qualitative data analysis as "a procedure of exploratory and inferring data to extract meaning, increase realizing, and expand practical information."

\subsection{Contributers of the survey}

The inspection happened at university the results for which were accumulated through a questionnaire planned to extract academics' opinions toward the use of Skype site, as a public media, to maintain conventional education method. The investigation questionnaires contained 34 items, developed by the examiner. The academics' reactions were noticeable in a straight line on the investigation. The questionnaire items were prepared in the form of reports to which the student had to answer on five-point degree. This degree extended between "strongly agree" to "strongly disagree."The questions were proposed to collect information about academics' agreement with the use of Skype as a writing class instrument.

It was delivered to five technology education academics for appraisal to indemnify the legality of the survey way. These members were requested to calculate the questionnaire technique and suggest any modification that should assist the survey. Then, good comments were obtained and some approvals were made and born in mind.

\subsection{Process}

Through this examination the lecturer:

- $\quad$ To produce a Skype site signifying the computer in education class notes and educations

- $\quad$ To disconnect the course Skype site from his personal page and interconnects with academics through it

- To notify the learners that they will not be watching their summary site, and regulating their site to "limit" assures that they will not see anything the others does not desire them to notice.

- $\quad$ To deliver the course Skype site the texts, videos, pictures, and posts that are pertinent to the writing course attempt in a weekly foundation.

- To assemble a "Skype Office Hours," in order to allocate academics opportunities to interconnect with him by Skype tool. This will offer them the chance to inquire writing inquiries or obtain extra criticism

- To declare for exams, quizzes, duties, or general college events that academics would be fond of.

\section{DATA AND DISCUSSION}

Along with research data, the students are amenable to utilize Skype in writing classes, and they are of the thought that such application will augment their practices in learning writing, rationally and expressively. The academics recognize that Skype-based scheme exercise was mainly hopeful and amazingly hopeful. In company with the interrogation questions, the contributors maintained that the media-based method improved their learning of academic English writing.

The data transmitted to the next examination question "What are the most and least part of the Skype base checks that were employed throughout the course term" were shown in chart1. It disclosed, according to the highest mean value, that the most significant item was number 7 with a mean value of 4.2 . "I utilized the 
Skype base to locate dissimilar multimedia that assist simplify the class points ". It was detected that items 18 , $34,9,24$ were very significant and have the maximum means $(4.1,4.04)$. These data explain the members most employed practices in the Skype base. The minimum mean was 2.9 for item 23. "The base was applied to acquire the notes and marking homework."

Table1. The rearranged assessment of points replies (derived from the highest average value)

\begin{tabular}{|c|c|c|c|}
\hline Item\# & Statement & Mean & Std. Dev \\
\hline 7 & I employed he Skype position to discover a new system assisting to make $\mathrm{s}$ the new idea simpler & 4.2 & 1 \\
\hline 18 & The position was utilized to insert or eliminate classmates & 4.1 & 1.026 \\
\hline 34 & $\begin{array}{l}\text { It is assumed that employing Skype for knowledge seem as a dynamic knowledge and it is a fine } \\
\text { device in instruction }\end{array}$ & 4.08 & 1,187 \\
\hline 9 & The Skype was used to deliver academics house works and implements to classes site & 4.04 & 0.865 \\
\hline 24 & It was applied to know the course duties deadline & 4.02 & 0.946 \\
\hline 10 & I t was used to acquire information about deadlines duties & 4 & 1 \\
\hline 20 & Sky was applied to obtain information about the first, second, and final test times & 3.94 & 1.008 \\
\hline 8 & I applied the Skype to get order about academics task and necessities & 3.92 & 1.096 \\
\hline 1 & Skype provided me the opportunity to select the writing language & 3.9 & 1.085 \\
\hline 25 & The Skype was employed to get information about day by day annotations from the lecturer & 3.88 & 1.013 \\
\hline 26 & The site was employed to add, remove, update subject materials & 3.88 & 0.992 \\
\hline 11 & The site was apply to get knowledge about lecturer Skype and remark & 3.86 & 1.041 \\
\hline 16 & Skype was employed to perceive others feedbacks and replications to negotiations & 3.86 & 1.099 \\
\hline 28 & Skype was exploited to get information about the classmates' work and development & 3.86 & 1.061 \\
\hline 13 & I employed the conversation for fast interconnection with others after class time & 3.82 & 0.905 \\
\hline 33 & Skype was employed to get revised materials about the individual page and messages & 3.76 & 1.465 \\
\hline 19 & Skype was employed by lecturer to express our conversation and members & 3.73 & 1.335 \\
\hline 15 & It was applied to talk about and reply questions shared the group of students topics & 3.65 & 1.165 \\
\hline 6 & The Skype was used to comprehend class materials and speeches. & 3.55 & 0.959 \\
\hline 30 & The Skype was employed to affix webs addresses that sustain the course topics & 3.55 & 1.292 \\
\hline 4 & I used the Skype to obtain information about class vocabulary and orientations & 3.53 & 1.12 \\
\hline 3 & Skype used to grasp information about class program and times & 3.51 & 0.938 \\
\hline 22 & The site was used to broadcast each student duty & 3.49 & 1.12 \\
\hline 29 & Skype was applied to save folders and matters as further recommendations & 3.49 & 1.227 \\
\hline 14 & Skype was employed to append class reports and update news & 3.43 & 1.099 \\
\hline 17 & Skype was employed to reply to other academics introduced images and materials or urgent like & 3.31 & 1.025 \\
\hline 21 & It was applied to clarify complex idioms & 3.22 & 3.22 \\
\hline 23 & Skype was employed to find the remarks and scoring training & 2.9 & 2.9 \\
\hline
\end{tabular}

Outcome answered to the next investigation dilemma "Are academics' opinions to using Skype as a sustaining instrument for course provision vary founded on preferred variables: year of learning, past knowledge with Skype, student occupation?" It disclosed that there were no statistically important variations at $(\alpha=0.05)$ in using Skype units because of academics majors. There are statistically important dissimilarities at $(\alpha=0.05)$ in using Skype units because of the year of study adaptable with the third and fourth year academics. The answer also, described that there are statistically important variation at $(\alpha=0.05)$ in using Skype units because of the past practice with Skype unpredictable. In support of academics with no Skype, use knowledge.

The data presented that using Skype position for academic writing reason is probably to be an inspiring issue for teaching and learning development. The Skype position for this survey has generated an dynamic learning atmosphere that could locate identical chances to present communication and have criticism from the learners and his/her academics. The examiner as an academic in higher teaching stage was very aggravated to apply social media, such as Skype and Twitter collections, as a teaching provision technique. It can be used in implicit learning situations. Advanced education teaching as the investigator practices is leaving toward applying the social media as a fraction of an implicit procedure between the learners and academics, and between academics themselves as informal learning scenery. This research has thrown up many questions in need of further investigation. If the debate is to be moved forward, a better understanding of setting needs to be developed.

\section{CONCLUSIONS}

To sum up, it demonstrates that Skype base, as a social media is a valuable device to be applied to offer writing themes and maintain learning. The principal theoretical implication of this study is that academics experienced calm while using the Skype base. Academics recording for the course designated their agreement of this media in learning academic writing. The data of this research was similar to those of other report complete by investigator accomplished to discover the impression and approach toward the use of social media 
in universities. In general, the results of the research signify that member's tendency in using Skype base, as social media, encourage, and provide them the chance to use technology in a helpful method. As the data of the research demonstrated, the mainstream of academics amended their abilities rapidly to employ the Skype proficiently. They sense that they support via this media in university and they have an efficiently learning knowledge throughout the procedure.

It may be presumed that expertise should be employed as directive device for vocabulary achievement. It has also been presented that this kind of education is favorable for distant language learners, as it significantly constructs self-confidence and amplifies students' attraction in the subject. The motives could be the incidence of contacts because of a developed language contribution. The survey illustrated that academics progressed in writing skill and self-confidence after being depicted its techniques using Skype. The learners in the survey realized this kind of instruction and were actually encouraged to challenge themselves to develop their English writing. In addition, the contributors started remarking and forwarding some suggestions connected to the plan subject to the teacher and to each other on Skype. The instructions via Skype appeared more attractive to academics. Operating on the Internet and managing each other through Skype anytime and anywhere is fashionable in these days.

\section{DIDACTIC INSIUATIONS}

\section{Future Research}

The evidence presented in this paper suggests that additional studies have to manage instruments and procedures to motivate on issues to expand the other learning skills like writing via social systems. Skype and other system media should be believed as an internalized situation.

More investigation and experimentation into the topic is strongly recommended to focus on the position of the learners' age and gender on the features of learning second language in a variety of cultures. As well, it should be presupposed that some devices could determine their English acquaintance enduring online instruments as Prensky [63] supposed that teachers in some situations might discontinue instruction, and initiate permitting academics to learn by themselves. However, with a small sample size, cautious must be applied, as the findings might not be valuable in every setting.

\section{REFERENCES}

[1] Koszalka TA and Ntloedibe-Kuswani G, Literature on the safe and disruptive learning potential of mobile technologies. Distance Education, vol. 31, no. 2, pp. 139-157, 2010.

[2] Ajjan, H and Hartshorne, R, "Investigating faculty decisions to adopt Web 2.0 technologies: Theory and empirical tests," Internet and Higher Education, vol. 11, pp. 71-80, 2008.

[3] Jones, N, et, all "Get out of MySpace," Computers and Education, vol. 54, pp. 776-782, 2010.

[4] Jadhav, D, Bhutkar, G and Mehta, V, "Usability evaluation of messenger applications for Android phones using cognitive walkthrough," 2013.

[5] SaadiyahDarus. The Current Situation and Issues of the Teaching of English in Malaysia. Presented at International Symposium of the Graduate School of Language Education and Information Sciences, 2009. [Online] Available: December 12, 2013 from http://saadiyahdarus.blogspot.com/

[6] Boyer, E. L, College, the Undergraduate Experience in America. New York; Harper \&Row, 1987.

[7] Joseph Kee-Kuok Wong, "Are the Learning Styles of Asian International academics Culturally or Contextually Based?" International Education Journal Educational Research Conference 2003 Special Issue, vol. 4, no. 4, 2004.

[8] Nowlan, A. G. P, "Motivation and Learner Autonomy Activities to Encourage Independent Study," 2008. [Online] Available: April 12, 2013 from http://iteslj.org/Techniques/Nowlan-Autonomy.html

[9] Cochrane TD, "Beyond the Yellow Brick Road: mobile Web 2.0 informing a new institutional elearning strategy, ALT-J, vol. 18, no. 3, pp. 221-231, 2010.

[10] Echeverría A, Nussbaum M, Calderón JF, Bravo C, Infante C, Vásquez A, "Face-to-face collaborative learning supported by mobile phones," Interactive Learning Environments, vol. 19, no. 4, pp. 351-363, 2011.

[11] Blyth, C, Research perspective on online discourse and foreign language learning', in Magnan, S. (ed.), Mediating Discourse Online. Philadelphia: John Benjamins Publishing Company, pp.47-72, 2008.

[12] Geraldine Mongillo \& Hilary Wilder, An Examination of all At-Risk College Freshmen's Expository Literacy Skills Using Interactive Online Writing Activities, vol. 45, no. 1, 2013.

[13] Long, M, 'Input and second language acquisition theory', in Gass, S. and Madden, C. (eds.), Input in second language acquisition. Rowley, Mass: Newbury House: 377-393, 1985.

[14] Long, M. 'The role of the linguistic environment in second language acquisition', in Ritchie, W. and Bhatia, T. (eds.), Handbook of second language acquisition. San Diego: Academic Press: 413-468, 1996.

[15] Chapelle, C.A, "CALL in the year 2000: Still in search of research paradigms?" Language Learning and Technology, vol. 2, no. 1, pp. 22-34, 1997.

[16] Salaberry, R, "CALL in the year 2000: Still developing the research agenda," Language Learning and Technology, vol. 3, no. 1, pp. 104-107, 1999. 
[17] Harrison, R. 'Profiles in online communities: social network sites for language learning - Live Mocha revisited', in Lamy, M.-N. and Zourou, K. (eds.), Social Networking for Language Education. Basingstoke, UK: Palgrave Macmillan: 100-116, 2013.

[18] Harrison, R and Thomas, M, "Identity in online communities: Social networking sites and language learning," International Journal of Emerging Technologies and Society, vol. 7, no. 2, pp. 109-124, 2009.

[19] White, R. W, "Motivation reconsidered: The concept of competence," Psychological Review, vol. 66, pp. 297-333, 1959.

[20] Deci, E. L and Ryan, R. M, Intrinsic motivation and self-determination in human behavior. New York: Plenum Publishing, 1985.

[21] Deci, E. L and Ryan, R. M, "Promoting self-determined education," Scandinavian Journal of Educational Research, vol. 38, pp. 3-41, 1994.

[22] Deci, E. L and Ryan, R. M, Handbook of self-determination research. Rochester, NY: University of Rochester Press, 2002.

[23] Deci, E. L, Vallerand, R. J, Pelletier, L. G, \& Ryan, R. M, "Motivation and education: The self-determination perspective," Educational Psychologist, vol. 26, pp. 325-346, 1991.

[24] Krashen, S. 'The input hypothesis and its rivals.' In N. C. Ellis (ed.), Implicit and explicit learning of languages, San Diego, CA: Academic Press, pp. 45-78, 1994.

[25] Pintrich, P. R and Schunk, D. H, Motivation in education: Theory, research, and applications. Ohio: Merrill, 1996.

[26] Brophy, J, Motivating academics to learn (2nd ed.). Mahwah, NJ: Lawrence, 2004.

[27] Yah Awang Nik, et, all., "The writing performance of undergraduates in University of Technology Mara, Terengganu Malaysia," Journal of Languages and Culture, vol. 1, no. 1, pp. 8-14, 2010.

[28] Kennedy, L. L. J, The effects of self-determination, theory on learning and motivation of repeating academics in a high school earth science classroom. PhD Thesis University of North Carolina at Greensboro, 2007.

[29] Helliwell, J. F and Putnam, R. D, "The social context of well-being," Philosophical Transactions of the Royal Society of Biological Sciences, vol. 359, pp. 1435-1446, 2004.

[30] Erlbaum. FOOTE, C, "See me, hear me: Chat with authors, record podcasts, and cover reference - all online and for free-with Skype," School Library Journal, vol. 54, no. 1, pp. 42-43, 2008.

[31] HERRING, S. C, "Computer-Mediated Communication: Linguistic, Social and Cross-Cultural Perspectives," Pragmatics and Beyond series. - Amsterdam: pp. 29-46. 1996

[32] PALLOFF, R. M and PRATT, K, "Building Learning Communities in Cyberspace: Effective strategies for the online classroom," San Francisco, CA: Jossey-Bass, pp. 206, 1999.

[33] QUILLEN, I. "Educators Move Beyond the Hype Over Skype," Education Week, 2011 [Online] Available: http://www.edweek.org/dd/articles/2011/02/09/02skype.h04.html. (retrived April 8, 2015).

[34] BRANZBURG, J, "Talk Is Cheap: Skype Can Make VoIP a Very Real Communication Option for Your School," Technology \& Learning, vol. 27, no. 8, pp. 36, 2007.

[35] Yates, S. J, Oral and written linguistic aspects of computer conferencing, pp. 29-46, 1996. [Online] Available: < http://bulba.sdsu.edu/ malouf/ling795/Yates.pdf> (retrieved April,8 2015).

[36] THOMANN, A, "Skype - A Baltic Success Story". credit-suisse.com," The Mixxer - a free educational website for language exchanges via Skype, 2006. [Online] Available: <http://www.language-exchanges.org/content/mixxer-freeeducational-website-language-exchanges-skype> (retrieved April,8 2015

[37] GRADDOL, D, "English next" [Online] Available: http://www.britishcouncil.org/files/documents/learning-researchenglish-next.pdf>. (retrieved April 8, 2015)

[38] Celce-Murcia, M, Teaching English as a second or foreign language (3rd. Ed.). Boston: Heinle\&Heinle, 2001.

[39] White, R and Arndt, V, Process Writing. London: Longman. 1991.

[40] Holton, D and Clarke, D, "Scaffolding and meta cognition," International Journal of Mathematical Education in Science and Technology, vol. 37, no. 2, pp. 127-143, 2006.

[41] Macharaschwili, C. E and Coggin, L. S, "A Skype-buddy model for blended learning," Journal of Interactive Learning Research, vol. 24, no. 2, 2013

[42] Elia, A, "Language learning in tandem via Skype ${ }^{\mathrm{TM}}, "$ CALL Technologies and the Digital Learner, vol. 6, no. 3, pp. 269-280, 2006.

[43] Beltrán, O. C, "The use of Skype ${ }^{\mathrm{TM}}$ chat for improving writing skills in an A2 adult learners group. Unpublished M.A. thesis in English Language Teaching -Autonomous Learning Environments," Universidad de la Sabana, Chía, Colombia, 2009.

[44] Romaña Correa, Y, "Skype ${ }^{\mathrm{TM}}$ conference calls: A way to promote speaking skills in the teaching and learning of English," PROFILE Issues in Teachers' Professional Development, vol. 17, no. 1, pp. 143-156, 2015.

[45] Gabriel, M. A., Campbell, B., Wiebe, S., McDonald, R. J \& McAuley, A, "The role of digital technologies in learning: Expectations of first year university academics," Canadian Journal of Learning and Technology, vol. 38, no. 1, 2012.

[46] Strang, K. D, "Skype synchronous interaction effectiveness in a quantitative management science course," Decision Sciences Journal of Innovative Education, vol. 10, no. 1, 2012

[47] Chou, H.-W, Lin, Y.-H, \& Chou, S.-B, "Team cognition, collective efficacy, and performance in strategic decisionmaking teams," Social Behavior and Personality: An international journal, vol. 40, pp. 381-394, 2012.

[48] Parker, J, Boase-Jelinek, D, \& Herrington, J. "Perceptions and reflections: Using Skype chat to build a community of learners. Murdoch," Retrieved from Research repository. Google Scholar, 2011.

[49] Cohen, F. F and Burkhardt, A, "Even an ocean away: developing Skype-based reference for academics studying abroad," Reference Service Review, vol. 38, no. 2, pp. 264-273, 2010. 
[50] Ab Manan, A Alias and A Pandian, "Utilizing a Social Networking Website as an ESL Pedagogical Tool in a Blended Learning Environment: An Exploratory Study," International Journal of Social Sciences and Education, 2012.

[51] Chenzi, C, Salehi, H, \& Yunusm, M, "Integrating Social Networking Tools into ESL Writing Classroom: Strengths and Weaknesses," English Language Teaching Journal, vol. 5, no. 8, pp. 42-48, 2012.

[52] Smethurst, L, "Student Inter-school Debating with Skype," [Online] Available: http://loisath.edublogs.org/2009/08/29/student-inter-school-debating-with-skype/ on December 4, 2010.

[53] Davis, V. A, "Using Skype in the Classroom (or just learning how to use it!)," 2006. [Online] Available: http://coolcatteacher.blogspot.com/2006/10/using-skype-in-classroom-or-just.html

[54] Mongillo, G and Wilder, H, "An examination of at-risk college freshmen's expository literacy skills using interactive online writing activities," Journal of College Reading and Learning, vol. 42, no. 2, 2012.

[55] Huang, X. S and Hsiao, E-L, "Synchronous and asynchronous communication in an online environment: Faculty experiences and perceptions," Quarterly Review of Distance Education, vol. 13, no. 1, 2012.

[56] Kno, B and Boswell, B. Overcoming challenges of distance education: Instructional technologies. International Journal of Instructional Technology and Distance Learning, vol. 8, no. 3, Retrieved from Academic Search Complete. Distance Education, vol. 13, no. 1, Retrieved from Academic Search Premiere database, 2011.

[57] Linnebrink, E \& Pintrich, P, The role of motivational beliefs in conceptual change. In M. Limon \& L. Mason (Eds.), reconsidering conceptual change issues in theory and practice. London: Kluwer Academic Publishers, 2002.

[58] Ciekanski, $\mathrm{M}$ and Chanier, T, "Developing online multimodal verbal communication to enhance the writing process in an audio-graphic conferencing environment," European Association for Computer Assisted Language Learning, 2008.

[59] Cheng, r, "Computer-mediated scaffolding in 12 academics' literacy development," Calico, vol. 28, no. 1, 2010.

[60] Murphy, E and Rodriguez-Manzanares, M. A, "Rapport in distance education," The International Review of Research in Open and Distance Learning, vol. 13, no. 1, 2012.

[61] Dey, I, Qualitative data analysis: A user-friendly guide for social scientists. London, UK: Routledge, 1993.

[62] Corbin, J and Strauss, A, Basics of qualitative research. Los Angeles, CA: Sage, 2008.

[63] Prensky, M, "The role of technology in teaching and the classroom," Educational Technology, vol. 46, no. 6, pp. 1-3, 1998. 